\title{
Images of Patronage in Khotan
}

\author{
Erika Forte
}

\section{Introduction}

Patronage of Buddhism at the highest levels of Khotanese society is attested to in literary sources that stress the close ties between political sovereignty and Buddhist religious power. These sources present the history of the kingdom as continuously intermingled with accounts of Buddhist epiphanic events, which occurred in connection with actions taken by the kings. The artistic production and the richness of Buddhist archaeological remains in Khotan prove that Buddhism greatly flourished there, and confirm that this prosperity was only possible through strong political and social support. However, how, and to what extent, this support worked in practice is difficult to establish.

Two kinds of written evidence refer expressly to royal patronage: legendary accounts, which underline royal agency in the foundation of basically all the important Buddhist institutions in Khotan; and the historical accounts of Chinese pilgrims, which mention royal support and involvement in the affairs of Khotanese monasteries. Additional evidence, yet to be systematically explored, concerns indigenous manuscripts and documents, like wooden tablets, and Chinese documents found mostly in the area of the Dandān-öiliq site, northeast of Khotan (map 2.1).

Expressions of patronage are less explicit in the art historical evidence from Khotan. To my knowledge, there are no paintings or sculptures that are clearly identifiable as a depiction of a royal patron or donor, nor do the few studied inscriptions on paintings give any hint in this direction. ${ }^{1}$ Khotanese royals are only depicted in the Mogao Caves (Chin. Mogao ku 莫高窟) at Dunhuang (敦煌) and in the Yulin Caves (Chin. Yulin ku 榆林窟), where they are identified by inscriptions (in Chinese). ${ }^{2}$ This evidence - chronologically later (1oth century) than the surviving, local Khotanese material-is related to Khotanese

1 See Ronald E. Emmerick, "Some Khotanese Inscriptions on Objets d'Art," The Journal of the Royal Asiatic Society of Great Britain and Ireland 3-4 (1968): 140-143.

2 For an overview see Sha Wutian 沙武田, “Dunhuang shiku Yutian guowang huaxiang yanjiu 敦煌石窟于蒖国王画像研究 [Studies in the Images of the King of Khotan at the Dunhuang Caves]," Xinjiang shifan daxue xuebao 新疆师范大学学报 Journal of Xinjiang Normal University 27.4 (2006): 22-30. 


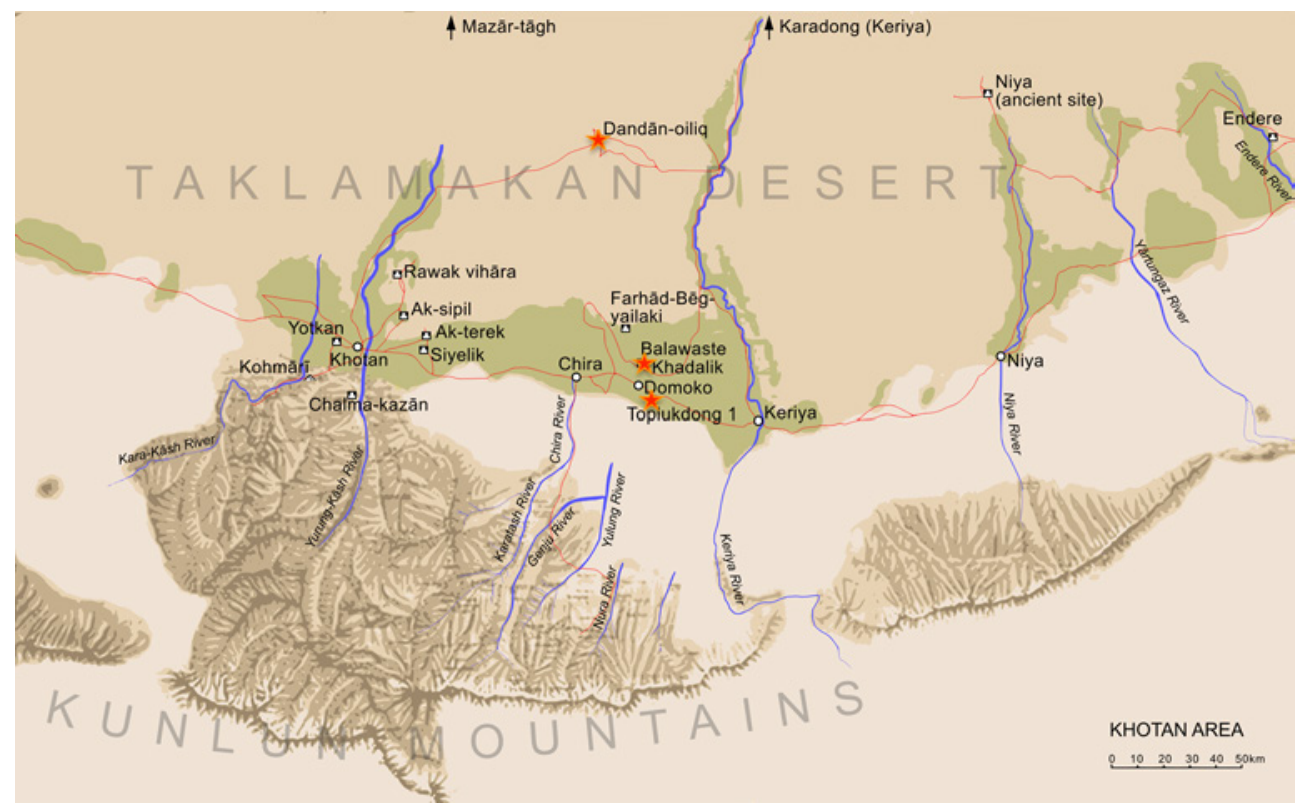

MAP 2.1 Main Buddhist sites of Khotan oasis, where depictions of legends have been found.

MODIFIED AFTER STEIN, ANCIENT KHOTAN, "MAP OF KHOTAN AREA," BY J. SCHÖRFLINGER

royalty connected with the Guiyijun (851-1036?, 歸義軍, Return-to-Allegiance Army) rulers. At that time, the Khotanese royal family chose to adopt a different, largely Sinitic, visual language in its expression of patronage.

The content of extant Khotanese art-which is exclusively Buddhist — can be divided into two groups: iconic depictions per se and depictions with narrative elements. In iconic depictions, frontal static images of Buddhas and (less frequently) bodhisattvas occupy the main space of the painting, with donors usually represented in smaller scale on the lower part. ${ }^{3}$ In the extant examples

3 Such examples are often seen in the murals at Dandān-öiliq, compare for instance, Marc Aurel Stein, Ancient Khotan, Detailed Report of Archaeological Explorations in Chinese Turkestan (Oxford: Clarendon Press, 1907), vol. 2, pls. III-V. Narrative depictions display one or more scenes of a story, usually visualized synoptically or in a conflated way. Narrative paintings found in Khotan have been described and analysed by Aurel Stein (Ancient Khotan, 119-122, 253-255, 259-261), Joanna Williams ("The Iconography of Khotanese Paintings," East and West 23.1-2 (1973): 147-154), Priatosh Banerjee ("Hārīti-Lakshmī from Dandan-Uiliq, Central Asia," in New Light on Central Asian Art and Iconography, ed. Priatosh Banerjee (New Delhi: Abha Prakashan, 1992), 46-54) and Lokesh Chandra ("The Khotanese Mural of Hariti at Dandan- 
from Khotan, donors kneel or stand, facing the central figure (normally a Buddha), with folded hands, holding incense burners, lotus flowers, or other plants, all common features of donors' portraits across Central Asian Buddhist visual evidence.

Donors often appear as family groups rather than individually. One of the best examples is shown in fig. 2.1. Here, the donors are depicted in the seat underneath the main image - an over life-sized sculpture of a Buddha in padmäsana ${ }^{4} \mathrm{~A}$ large vase with a lotus flower occupies the centre of the composition, on both sides of which are six kneeling figures (three females on the right and three males on the left of the vase). They are likely members of a family group. There is also an image of a monk, who may be related to the family represented or have taken part in the donation process. ${ }^{5}$ There is also an inscription that runs above the heads of the donors. However, the content of the inscription does not seem to be directly related to the donor portraits. ${ }^{6}$

This is but one example of donors portrayed in iconic scenes. As for the other category of Khotanese painting mentioned above, i.e. depictions featuring narrative elements, it should be noted that in Khotanese Buddhist art, depictions of the Buddha's life story (Skt. jātakas or avadānas) are peculiarly practically absent. Instead, the surviving narrative paintings from Khotan seem to favour themes related to local legends. ${ }^{7}$ Since legends make up the

Uiliq," in Purābhāratī. Studies in Early Historical Archaeology and Buddhism, 2, ed. Buddha Rashmi Mani and Bindeshwari Prasad Sinha (Delhi: Sharada Publishing House, 2006), 243249). See also section 2.1 in this chapter.

4 The sculpture was found by Aurel Stein in the temple Ta.i. in Tarishlak, near Mayaklik, about $30 \mathrm{~km}$ north of the town of Khotan. For a detailed description see Marc Aurel Stein, Serindia. Detailed Report of Explorations in Central Asia and Westernmost China (Oxford: Clarendon Press, 1921), vol. 3, 1282 (inv. n. Ta.oo9), fig. 324 (photograph of the sculpture in situ), and vol. 4, plate cxxvi.

5 In this specific painting the monk seems to wear boots. Monks with boots are found occasionally in other sites from Central Asia. The interpretation of this iconography is not yet settled and may carry different meaning according to the geographical/cultural context of the findings. This topic, with regard to Khotan, certainly needs further research and will be dealt with in another article.

6 The only study of this inscription I am aware of was published by Frederick Pargiter in 1913 . Pargiter writes that the inscription is in Sanskrit "of a poor quality." The content is a verse, written to honour the painting, and concludes with the wish of gaining "blessedness [...] in the principle of the auspicious Law" (Frederick Pargiter, "Inscription on a Painting at Tarishlak," The Journal of the Royal Asiatic Society of Great Britain and Ireland (1913): 400-401).

7 An exception, if the hypothetical reading by Joanna Williams is correct, is the evidence of a mural painting from the small temple D.II at Dandān-öiliq documented by Aurel Stein, which might represent a scene from the Sudhanajātaka. See Williams, "Khotanese Paintings," 153154 and fig. 69 . 


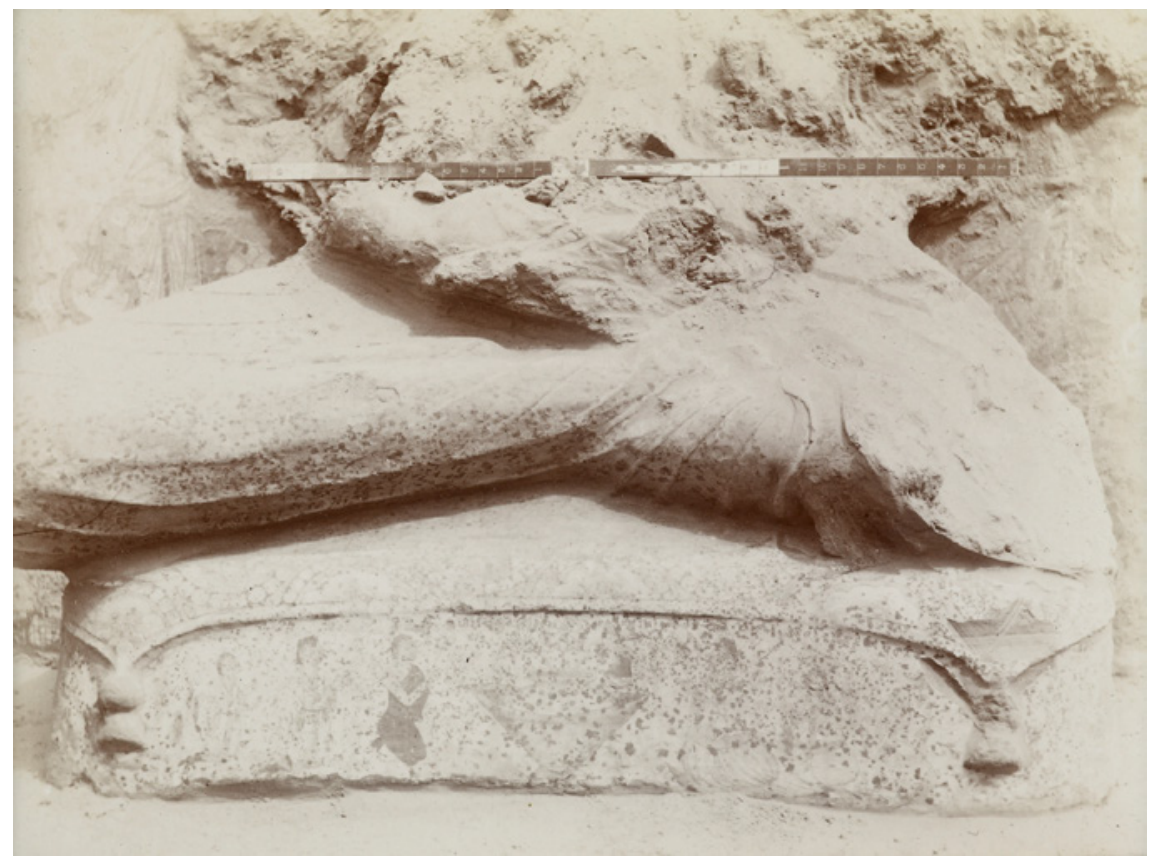

FIGURE 2.1 Remains of a Buddha sculpture with painted base with donors. In situ, from the temple Ta.i. in Tarishlak, Khotan, ca. 7 th/8th c. (?).

STEIN ARCHIVE PHOTO 392/26(691), (C) BRITISH LIBRARY

bulk of the material related to patronage in Khotan, in what follows we shall look at this in greater detail.

Khotanese legends are preserved in a variety of literary sources written in Khotanese, Chinese, and Tibetan, that essentially belong to the realm of Buddhism. The greatest documentation derives from a group of Tibetan texts, the contents of which probably stem from Khotanese literary works no longer extant. Of particular significance for the present inquiry are the Li yul lung bstan pa [Prophecy of the Li Country] ${ }^{8}$ and the Liyul chos kyi lo rgyus [Religious Annals

8 English translation by Ronald Emmerick, Tibetan Texts Concerning Khotan (London: Oxford University Press, 1967). For a recent Chinese translation see Zhu Lishuang 朱丽双, “Youguan Yutian de zangwen wenxian: fanyi yu yanjiu 有關于闐的藏文文獻: 翻譯與矿究. Tibetan Texts Concerning Khotan: Translations and Annotations" (Post-doc degree diss., Peking University, 2011). 
of the Li Country, P. T. 960]. ${ }^{9}$ In these texts, the legends are arranged according to the genealogy of Khotanese kings, who provide a historical setting and play a role in the stories. The stories are essentially Buddhist epiphanic events, meant to convey the involvement of Khotanese royalty in the establishment of monasteries.

We do have evidence of the existence of a number of monasteries mentioned in these legends, which appear in documents from Khotan and in Chinese historical literature-especially Buddhist travelogues. ${ }^{10}$ Moreover, some of the kings mentioned therein were actually historical figures. ${ }^{11}$ Notwithstanding their legendary and propagandistic flavour, on the whole these texts are basic chronicles concerning the founding of Buddhist temples in Khotan, and provide a valuable list of temple names and their royal patrons. The legends especially promote the connection between Buddhism and the royal lineage, and as such convey both political and religious messages.

$9 \quad$ English translation is in Frederick W. Thomas, Tibetan Literary Texts and Documents Concerning Chinese Turkestan, vol. 1 (London: Royal Asiatic Society, 1935), 303-323; transcription and Chinese translation in Zhu Lishuang, "Youguan Yutian de zangwen wenxian," $75^{-100 .}$

Zhang Guanda and Rong Xinjiang compiled a list of the most famous monasteries that are documented in historical literature and manuscripts. In some cases, it is possible to match Tibetan, Khotanese, and Chinese names' equivalents. See Zhang Guangda 張廣達 and Rong Xinjiang 榮新江, Yutian shi congkao (zengding ben) 于闐史叢考(増訂本), Collected Inquiries on the History of Khotan. New Edition (Beijing: Zhongguo renmin daxue chubanshe, 2008), 224-239. In the course of his extensive explorations in Khotan in 1900-1901, Aurel Stein tried to identify the actual location of the monasteries mentioned in the written sources. See Stein, Ancient Khotan, 223-235.

11 See James Hamilton, "Les règnes khotanais entre 851 et 1001," in Contributions aux études de Touen-houang, ed. Michel Soymié (Genève: Librairie Droz, 1979), 49-54; James Hamilton, "Sur la chronologie khotanaise au Ixe-Xe siècle," in Contributions aux études de Touen-houang, vol. III, ed. Michel Soymié (Paris: Publications de l'École française d'Extrême-Orient, 1984), 47-53; John Hill, "Notes on the Dating of Khotanese History" Indo-Iranian Journal 31.3 (1988): 179-19o; Zhang Guangda 張廣達 and Rong Xinjiang 榮新 江, “Guanyu Hetian chutu Yutian wenxian de niandai ji qi xiangguan wenti 關於和田出 土于閴文獻的年代及其相關的問題 [On the Dating of some Khotanese Documents Discovered in Khotan and Related Problems]," Tōyō gakuhō 東洋学報 [Journal of East Asian Studies] 69 (1988):59-86; Prods Oktor Skjærvø, "Kings of Khotan in the Eighth Century," in Histoire et cultes de l'Asie Centrale préislamique: sources écrites et documents archéologiques: actes du colloque international du CNRS, Paris, 22-28 novembre 1988, ed. Paul Bernard and Franz Grenet (Paris: Éditions du CNRS, 1991), 255-278; Prods Oktor Skjærvø, "The End of Eighth-century Khotan in its Texts," Journal of Inner Asian Art and and Archaeology, 3.2008 (2009): 119-144; Yoshida Yutaka 吉田豊, Kōtan shutsudo 8-9 seiki no Kōtan go sezoku bunsho ni kan suru oboegakiコータン出土 8-9 世紀のコータン 語世俗文書に関する覚え書き. Notes on the Khotanese Documents of the 8th-gth Centuries Unearthed from Khotan (Kobe: Kobe City University of Foreign Studies, 2006). 
2.1

The Legend of the Silk Princess

Archaeological material provides examples of how Khotanese local legends are transposed into visual forms, particularly in wall paintings and wooden votive panels. Previous research has identified the subjects of some of these paintings, based on Buddhist literary sources from and about Khotan. A wellknown example is the legend of the Silk Princess, which concerns the introduction of silk manufacture in Khotan. The legend is connected with the founding of Mashe (麻射) (or Lushe 鹿射) Monastery (Ma dza in the Tibetan sources). ${ }^{12}$ It has been transmitted in two different versions: a Tibetan one, preserved in the Prophecy of the Li Country, and a Chinese one, recorded by Xuanzang (600/602-664, 玄焋). ${ }^{13}$

The story relates that the king of Khotan, Vijaya Jaya, ${ }^{14}$ sought a marriage to a Chinese princess (named Puñeśvar in the Tibetan version), presumably with the intention of gaining access to the secret of silk production in China. At that time, the Chinese emperor forbade people to take silkworm eggs and mulberry tree seeds outside of the country. When it was time for the Chinese bride to leave China, the king of Khotan, through his envoy, informed his future spouse that no silk was produced in Khotan, subtly convincing her to take mulberry seeds and silkworms with her in order to provide herself with fine silk once there. The princess cunningly concealed the seeds and the silkworm eggs in her hair, and passed the Chinese borders without being checked by the guards.

12 In Western publications this name is spelled Ma źo, Ma źa or Ma źi (see Harold Walter Bailey, Khotanese Texts IV. Saka Texts from Khotan in the Hedin Collection (Cambridge: Cambridge University Press, 1961), 9.

13 For the story in the Li yul lung bstan pa see Emmerick, Tibetan Texts, 32-35. The legend reported by Xuanzang can be read in his Da Tang xiyuji 大唐西域記, English translation in Li, Rongxi, The Great Tang Dynasty Record of the Western Regions. Translated by the Tripitaka-Master Xuanzang under Imperial Order. Composed by Śramana Bianji of the Great Zongchi Monastery (Taishō, Volume 51, Number 2087), (Berkeley, California: Numata Center for Buddhist Translation and Research, 1996), 382-384. A synopsis of the two versions, the Tibetan and the Chinese texts, can be read in Williams, "Khotanese Paintings," 149, and in Stein, Ancient Khotan, 229-230.

14 He is the 14th king of Khotan in the genealogy of the Tibetan texts. According to Hill, the reign of this king (and therefore the introduction of silk technology to Khotan) should be placed in the first half of the 1st century (John E. Hill, "Appendix A: The Introduction of Silk Cultivation to Khotan in the 1st Century CE," September 2003, accessed May 02, 2018. <https://depts.washington.edu/silkroad/texts/hhshu/appendices.html\#a>). Recently Zhu Lishuang proposed dating the reign of this king to the early 3rd century CE, see Zhu Lishuang 朱丽双, “Yutianguo Shouji suozai zaoqi Yutian wangtong yanjiu «于阗国授 记》所载早期于阗王统矿究 Chronology of Early Khotan Kings According to the 'Prophecy of the Li Country'," in Tansuo Xiyu wenming. Wang Binghua xiansheng bashi huadan zhushou lunwenji 探索西域文明一王炳华先生八十华诞祝寿论文集, ed. Meng Xianshi 孟宪实 et al. (Shanghai: Zhongxi shuju, 2017), 199-213. 


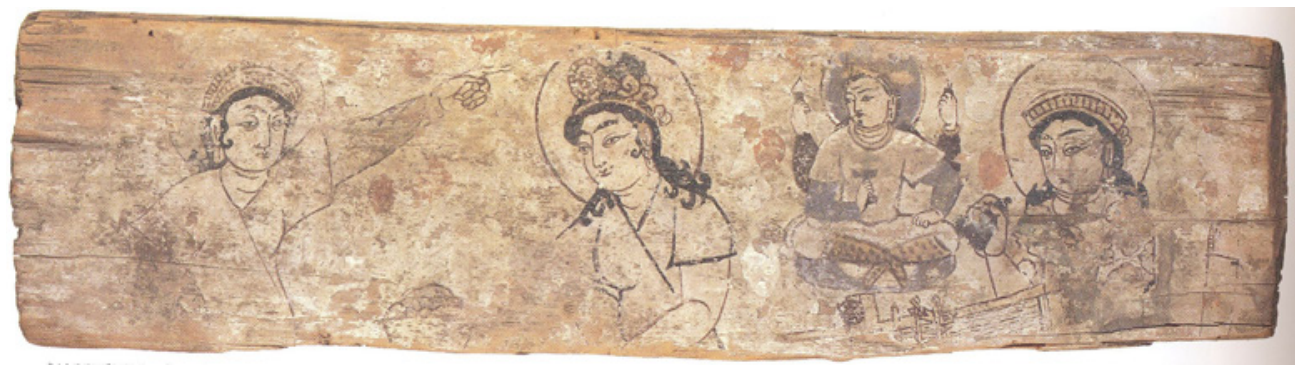

FIGURE 2.2 Painted wooden panel, $12 \times 46 \mathrm{~cm}$. Excavated at Dandān-öiliq, Khotan, temple D.X, ca. 7 th/8th century (?).

1907,1111.73, BRITISH MUSEUM

The place where the princess first deposited the precious silkworm eggs and planted the mulberry tree seeds before arriving at the capital of the kingdom of Khotan, is where the Mashe/Ma dza Monastery was later erected. Since the monastery foundation no one in Khotan was allowed to kill silkworms, and sericulture became a flourishing activity protected by the Khotanese kings. ${ }^{15}$

Eight depictions of this legend have been found in the sites of Dandān-öiliq and Khadaliq (map 2.1), attesting to its local popularity. ${ }^{16}$ The most famous and best preserved depiction is on a wooden panel excavated from the temple D.X of Dandān-öiliq (fig. 2.2), now at the British Museum. ${ }^{17}$ It shows a female figure on the left pointing at the headdress of another female figure at the centre of the composition. In front of the central figure is a basket filled with cocoons (?). On the right side, a woman is represented with a loom and holding a comb. Behind the central figure, there is a male deity with four arms and in Central Asian attire, who has been identified as a local god, the protector of silk manufacture. ${ }^{18}$

The same key elements appear in another wooden panel, this time arranged vertically (fig. 2.3). It was collected in Khotan by N.F. Petrovskij, reportedly from the site of Dandān-öiliq, and is now part of the Central Asian collection

15 The royal monastery was under the protection of the deities Ratnabala and Ratnaśüra.

16 For a list and description of these panels see Williams, "Khotanese Paintings," 147-150. Three of them were excavated by Stein in Dandān-öilïq from three different shrines; one panel was found in Khadaliq (also by Stein); four other panels were purchased by locals and are said to come from Dandān-öilïq, but the archaeological context remains unclear. Stein, Ancient Khotan, plate LXVII, object D.X.4.

18 Natalia Diakonova, "A Document of Khotanese Buddhist Iconography," Artibus Asiae 23.3-4 (1960): 229-232. Beside those that have a more 'narrative character' there are panels that display only this single deity. See Williams, "Khotanese Paintings," 15o, figs. 59,62 and 63 . 


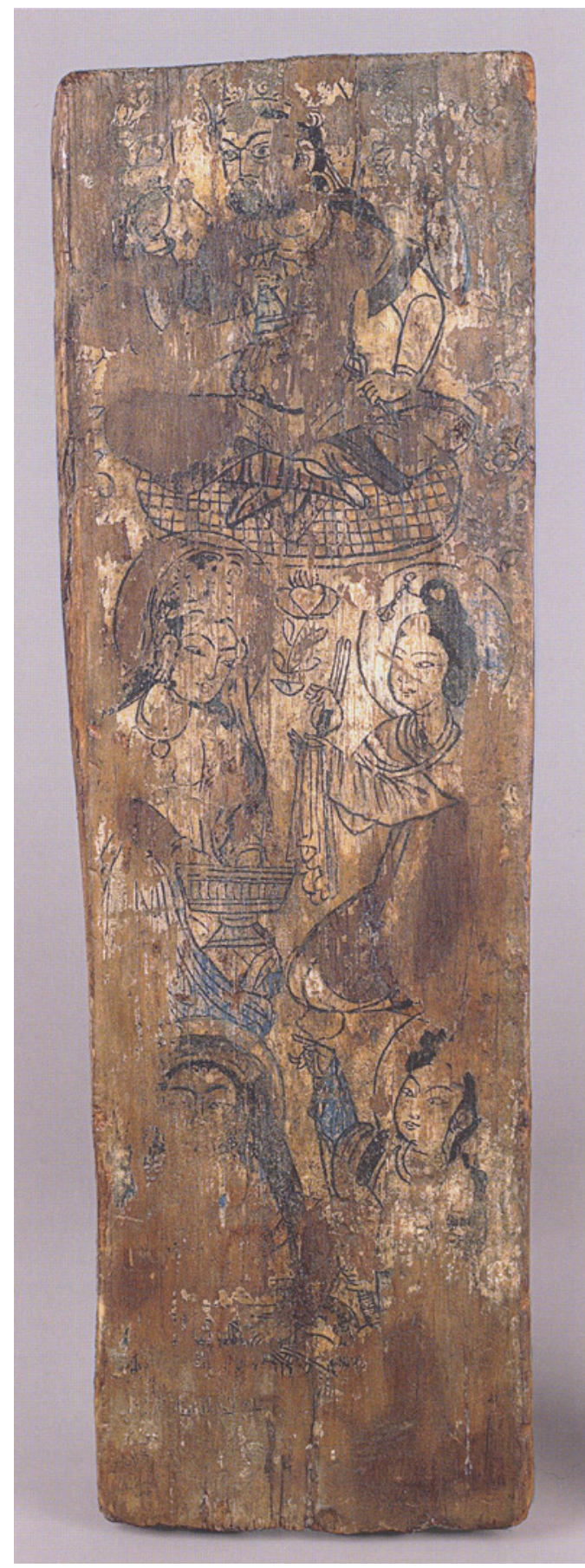

FIGURE 2.3

Painted wooden tablet, $49,5 \times 13 \mathrm{~cm}$.

Found in Dandān-öiliq, Khotan.

ГA-1125, STATE HERMITAGE MUSEUM 
of the State Hermitage Museum. At the top of the panel is the four-armed deity. At the bottom, a female figure points at the headdress of another figure. In the centre, there are two other female figures. The one on the left of the composition is kneeling facing the one on the right, who has her hands plunged into a large stemmed bowl, probably in the act of washing the cocoons.

We know that the Mashe/Ma dza Monastery still existed at the time of Xuanzang's sojourn in Khotan. Xuanzang visited the site of the monastery, describing its location as at a distance of five to six li (里, approximately 3 kilometres) south-east of the capital of the kingdom. ${ }^{19}$ Stein identified the place where the monastery once stood with the site of the Muslim shrine of Kum-i-Shahīdān. A later hypothesis by Li Lingbing (李呤屏) favours the archaeological remains of Basai (巴塞), found near the village of Halal-bagh (Chin. Alalebage 阿拉勒巴格) as corresponding to this famous monastery. ${ }^{20}$ Both sites are located on the western-southwestern outskirts of present city of Khotan.

The number of objects depicting this legend underscores the fact that the monastery had a special meaning for Khotanese Buddhists. It is intriguing that all of these depictions come from an area that it is quite far from the possible original locations of the monastery: Dandān-öiliq and Khadalik are located more than a hundred kilometres away from present Khotan, to the northwest and west respectively. I will return to this question below.

\subsection{The Legend of the Gomati Monastery}

Other legends recorded in Chinese and Tibetan texts have been identified in Khotanese painting (but with less certainty than the Silk Princess case) ${ }^{21}{ }^{2}$ Research on visual depictions of legends in Khotan remained dormant, which is largely due to the fact that no further discoveries of Khotanese painting have

19 A li at the time of Xuanzang would correspond to ca. 56o meters, therefore the distance would be approximately between ca. 2.8 and 3.3 kilometres. The site of the ancient capital has been located in Yotkan, southwest of present Khotan city (Stein, Ancient Khotan, 190 and 199-206).

20 Stein, Ancient Khotan, 23o. Li Lingbing's location is based on the hypothesis that the capital of the kingdom should be located in Halal-bagh and not in Yotkan. Basai's distance from Halal-bagh would correspond to that given by Xuanzang (Li Lingbing 李呤屏, “Gudai Yutian guodu zai yanjiu 古代于阗国都再研究 [The Ancient Capital of the Kingdom of Khotan Re-considered]," Xinjiang daxue xuebao 新疆大学学报 Journal of Xinjiang University 3 (1989): 45-46. The site now called Alalebage fosi yizhi (Chin. 阿拉勒巴格佛 寺遺址, remains of the Halal-bagh Buddhist Monastery) seems to be a tourist attraction in the area of Khotan.

21 See the discussion of the paintings identified by Stein in Williams, "Khotanese Paintings," 152-154, and Chandra, "The Khotanese Mural of Hariti at Dandan-Uiliq." 
sustained the interest of scholars on this topic. However, in the last decade, the resumption of archaeological fieldwork in Khotan has brought to light new evidence concerning Khotanese painting. This material provides valuable and significant data to this topic.

Of particular relevance is a painting recovered from the structure known in Chinese archaeological reports as Toplukdong Site no. 1, or Toplukdong Small Temple (Chin. Topulukedong xiao fosi 托普鲁克墩小佛寺), near Domoko (Chin. Damagou 达玛沟), located in the south-eastern area of the Khotan oasis (map 2.1). ${ }^{22}$ The painting depicts a standing male figure in Central Asian clothing, encircled by a halo, holding a halberd (?), and accompanied by a deer (fig. 2.4). The painting alludes to a scene from the legend of the origin of the Gomati vihära - another famous monastery founded by the royals of Khotan. ${ }^{23}$

The legend of the Gomatī Monastery (Tib. Hgum tir, Kh. Gūmattīrä) ${ }^{24}$ is found in both the Prophecy of the Li Country and the Religious Annals of the Li Country. ${ }^{25}$ The story describes, with some variations, that after the introduction of Buddhism to Khotan, there was a period when seven generations of kings appeared, in the course of which no monasteries were built in Khotan, that is, until we arrive at the eleventh king of Khotan, Vijaya Vīrya: One day, he saw a golden and silver light radiating from outside his castle. After pursuing the source of the light, Vijaya Vīrya discovered it was emanating from a deer, which immediately transformed itself into the deity Samjñ̃aya (the

22 The site of Toplukdong was investigated from 2002 to 2010 and revealed the remains of three structural units (Site no. 1, no. 2 and no. 3) that were part of a large monastic complex in use between the 6 th/7th century and 1oth century. Zhongguo shehui kexueyuan kaogu yanjiusuo Xinjiang kaogudui 中国社会科学院考古研究所新疆队, “Fulu: Xinjiang Hetian diqu Celexian Damagou fosi yizhi de faxian yu yanjiu 附录:新疆和田地区策 勒县达玛沟佛寺遗址的发掘与研究 [Appendix: The Excavation and Research on the Buddhist Monastery Site of Domoko, in Cele County, Khotan, Xinjiang]," in Dandan wulike yizhi 丹丹乌里克遗址, Dandan Oilik Site. Report of the Sino-Japanese Joint Expedition, ed. Zhongguo Xinjiang wenwu kaogu yanjiusuo 中国新疆文物考古研究所 et al. (Beijing: Wenwu chubanshe, 2009), 293-333.

23 Erika Forte, "On a Wall Painting from Toplukdong Site no. 1 in Domoko: New Evidence of Vaiśravana in Khotan?" in Changing Forms and Cultural Identity: Religious and Secular Iconographies. Papers from the 2oth Conference of the European Association for South Asian Archaeology and Art held in Vienna from 4th to gth of July 2010, Vol. 1, South Asian Archaeology and Art, ed. Deborah Klimburg-Salter and Linda Lojda (Turnhout: Brepols, 2014), 215-224.

24 Emmerick, Tibetan Texts, 95b.

25 For the story in the Li yul lung bstan pa see Emmerick, Tibetan Texts, 28-33 (transliteration and English translation), and Zhu Lishuang, "Youguan Yutian de zangwen wenxian," 42 (transcription and Chinese translation). For the English translation of the legend in the Li yul chos kyi lo rgyus see Thomas, Tibetan Literary Texts, 306-307; transcription and Chinese translation: Zhu Lishuang, "Youguan Yutian de zangwen wenxian," 78-79. 


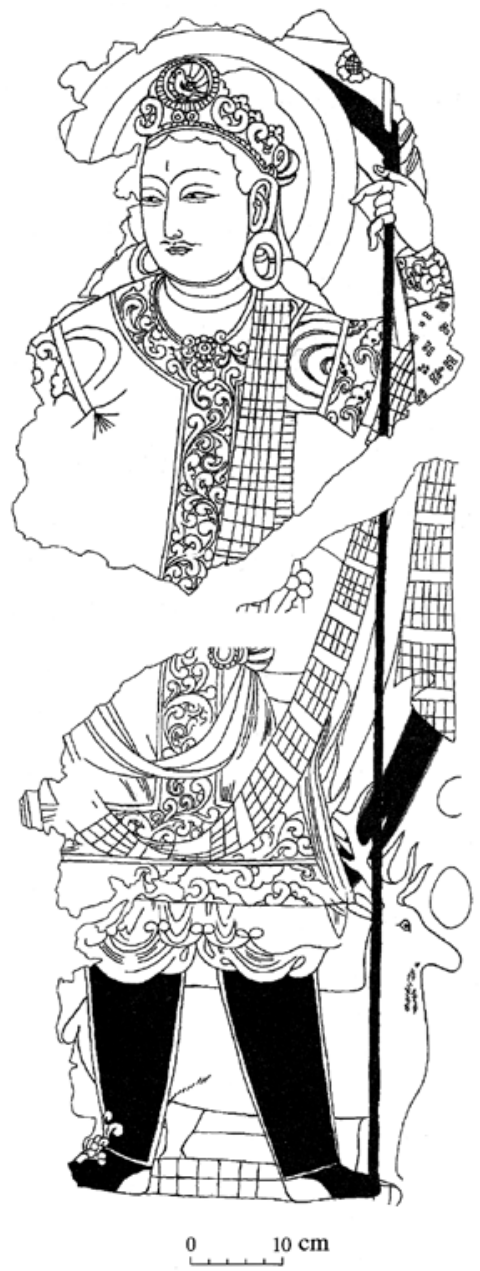

FIGURE 2.4

Line drawing of the painting found in Toplukdong Small Temple in Domoko, Khotan, 7 th/9th c. (?). XINJIANG ARCHAEOLOGICAL TEAM, THE EXCAVATION ON THE BUDDHIST SITE OF DOMOKO, 300, FIG. 14

mahāsenāpati of the yakșas). Samjñāya told the king to build a vihāra in that spot, so that Buddhadūta and three other arhats would come there and expound the dharma to the king. This vihära became known as Gomatī Monastery.

The story of the founding of the Gomati Monastery is linked to the legend of the Gautośan ${ }^{26}$ vihāra. Another miraculous event followed the construction of

26 The Gautośan Hill (hgehu to śan in Emmerick, Tibetan texts, 30, 178a4/a) of the Tibetan texts is none other than Mt. Gośrnga (Oxhorn, Chin. Niujiaoshan 牛角山 otherwise known in Sanskrit as Gośīrșa, Oxhead Mountain, Chin. Niutoushan 牛頭山), and perhaps the most famous place in Khotan's sacred topography, as described in ancient sources. 
the Gomatī Monastery. A child got lost in the vicinity of the Gomatī. While searching for him, the king and his people arrived in a small valley at the foot of the Hill of Gautośan, where they found a stüpa containing the relics of the past Buddha Kāśyapa. Recognising the sacredness of the place, king Vijaya Virya ordered the construction of a monastery there. Afterwards, the child was found safe. The end of the story stresses that in these two vihäras (i.e. Gautośan and Gomatī), manifestations and signs occurred, and that "they are to be considered the chief among the vihäras held to exist in the Li country." ${ }^{27}$ It is said that both monasteries are protected by Vaiśravaṇa, Samjjñāya, and the Nāga King Gṛhāvatapta.

The painting on the southern wall of the Toplukdong temple depicts the moment in the story when the deer transforms itself into the deity Samjñāya. This reference is particularly significant if we consider the position of the painting itself and the layout of the temple: Samjñnaya's depiction occupies the entire wall on the left side of the entrance, facing the main statue (fig. 2.5). On the right side of the entrance, another standing deity of similar proportions is depicted. Although this second deity cannot be identified precisely, there is little doubt that these two images served as protectors of the temple. ${ }^{28}$ Therefore, this could be read as providing a pictorial correspondence of the vow made by the deities Saṃjñāya, the Nāga King Gṛhāvatapta, and Vaiśravaṇa, to protect the Gomatī Monastery at the conclusion of the story. Samjñ̃aya, paired with another deity (Gṛhāvatapta?), might be interpreted as guarding the temple.

Three other depictions of this divinity from Khotan survive that likely allude to the same legend, in each of which a figure (with boots and wearing either Central Asian attire or armour) appears with a deer. ${ }^{29}$ Although the surviving pictorial evidence of the legend of the Gomati Monastery are less numerous than the depictions we have of the legend of the Silk Princess, there is no doubt that the story of the Gomati was popular in Khotan, especially because of the importance this monastery enjoyed in the Buddhist activities of the kingdom.

\footnotetext{
$27 \quad$ Emmerick, Tibetan Texts, 33.

28 This painting is fragmented, with only its lower portion visible. The preserved part shows only that the figure is wearing a dhoti tied up to the knees and has bare feet resting on a cushion. See Forte, "On a Wall Painting from Toplukdong," 217-219, figs. 2-7 and 221, note 12.

29 Williams, "Khotanese Paintings," 136-138; Forte, "On a Wall Painting from Toplukdong," 220-222, figs. 8-10.
} 


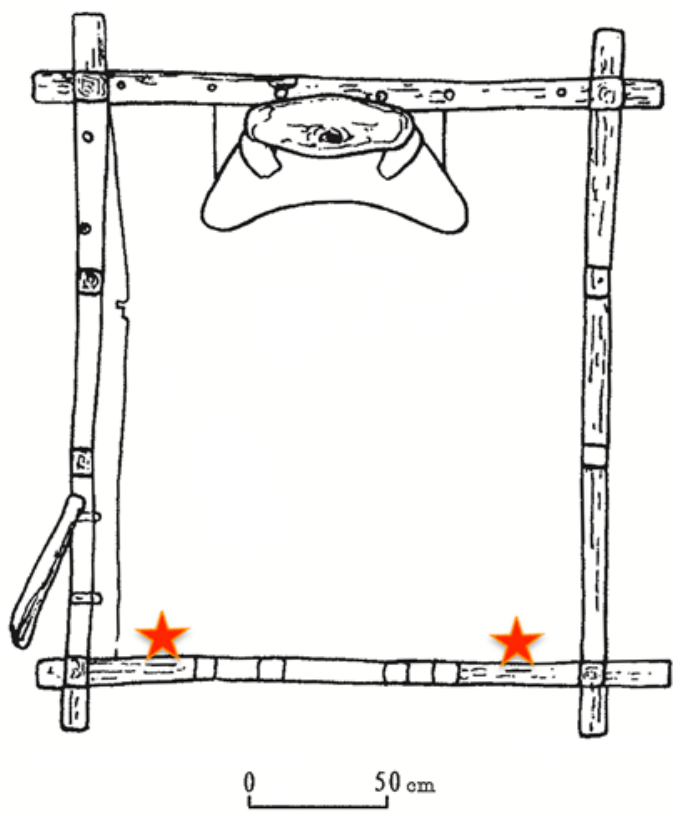

FIGURE 2.5

Plan of the Toplukdong Small Temple showing the positions of the paintings of Samjñāya and another protector, Domoko, Khotan.

MODIFIED AFTER XINJIANG ARCHAEOLOGICAL TEAM, THE EXCAVATION ON THE BUDDHIST SITE OF DOMOKO, 294-295, FIGS. 3 AND 4

2.2.1 Gomatì: A Great Monastery Founded by Royals for State Protection The existence of the Gomatī Monastery was first reported by Faxian (ca. 340before 423, 法顕), who lodged there during his stay in Khotan at the beginning

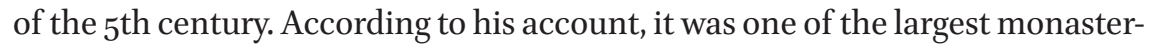
ies in the country, hosting three thousand monks of the Mahāyāna, and was favoured by the king. The Gomatì was one of the fourteen Great Monasteries (Chin. da sengjialan 大僧伽藍) in Khotan and took part in an important local Buddhist festival, where sacred Buddhist images were brought in procession to the city. The images were placed on richly decorated carts (one for each monastery) and carried to the city gate from a place on the outskirts from the city. The cart from the Gomati Monastery was the first one to set off to the city. When the carts approached the city, the king would go, barefoot, from his palace to outside of the city gate to welcome the images and make offerings, taking off his crown while doing so. The carts would then enter the city showered by flowers the queen and her maids scattered from the top of the gate. ${ }^{30}$ This

30 Gaoseng Faxian zhuan 高僧法顯傳 [Biography of the Eminent Monk Faxian], T. 2085.51, 857 b-c. Most recent translations are: Rongxi Li, A Biography of the Tripitaka Master of the Great Ci'en Monastery of the Great Tang Dynasty. Translated from the Chinese of Śramana Huili and Shi Yancong (Taishō, volume 50, Number 2053) (Berkeley, California: Numata Center for Buddhist Translation and Research, 1995), 155-214; Max Deeg, Das 
festival took place in Khotan every year in spring, lasted several days, and was apparently one of the most famous yearly events in the region.

The account by Faxian is the earliest mention of the Gomati Monastery in Chinese literary sources. Another reference-dating from the first decades of the $5^{\text {th }}$ century - is found in the biography of Dharmakșema (385-433, Chin. Tanwuchen 曇無識), which says that the Indian monk Buddhasena resided in the Gomatī Monastery of Khotan. ${ }^{31}$ Other mentions are found in Chinese historical literature and Buddhist literature from the Tang (618-907, 唐) period. ${ }^{32}$ The name of the monastery also appears on wooden tablets written in Khotanese ${ }^{33}$ and in Khotanese documents from Dunhuang, up to the 1oth century. However, the date of the foundation of the Gomati Monastery remains unknown. The period of the reign of Vijaya Virya - the eleventh king of Khotan said to have sponsored its foundation-is also unknown. ${ }^{34}$ Whenever it was founded, the Gomatì Monastery institution lasted for at least five centuries (from the first dated mention at the beginning of the $5^{\text {th }}$ century to the last one at the end of the 1oth century).

The legend as it appears in Tibetan texts underlines the direct connection between this monastery and the royals of Khotan. Faxian's account corroborates this fact. It was also at a royal command that Faxian and his companions were lodged in this monastery. Faxian informs us that it was a "Great Monastery" (Skt. mahāsamghārāma, 大僧伽藍, a term, the meaning of which is still not entirely clear within that context, but might be an indication that monasteries

Gaoseng-Faxian-Zhuan als religionsgeschichtliche Quelle: der älteste Bericht eines chinesischen buddhistischen Pilgermönchs über seine Reise nach Indien mit Übersetzung des Textes (Wiesbaden: Harrassowitz, 2005); and Jean-Pierre Drège, tr., Mémoire sur les pays bouddhiques (Paris: Les belles lettres, 2013).

$31 \quad$ Sylvain Lévi, "Notes chinoises sur l'Inde: IV. Le pays de Kharoșțra et l'écriture Kharoșțī̄," Bulletin de l'École française d'Extrême-Orient 4.3 (1904): 543-579, 556. The biography of Dharmakșema is in the Gaosengzhuan 高僧傳 [Biographies of Eminent Monks], T. 2059.5o, 335 c16-337bo4 (the passage on the Gomatī is at p. 337ao7-o9).

32 For an overview of the sources where the Gomati Monastery is mentioned, see Zhang Guangda and Rong Xinjiang, Yutian shi congkao, 228-230.

33 Duan Qing 段晴 and Wang Binghua 王炳华, “Xinjiang xin chutu Yutianwen mudu wenshu yanjiu 新疆新出土于闐文木覑文書研究 [A Newly Discovered Khotanese Wooden Document from Xinjiang]," Dunhuang Tulufan yanjiu 敦煌吐魯番研究 [Journal of the Dunhuang and Turfan studies] 2 (1996): 1-12. This is a contract of sale written on a wooden tablet. According to Duan Qing, its redaction should be earlier than the Tang period.

34 There is still uncertainty on the chronology of Khotanese kings for the period preceding the Tang Dynasty. Thomas suggests that Vijaya Virya could be placed in the 1st to 2nd centuries (Thomas, Tibetan Literary Texts, 7). Zhu Lishuang argues that the eleventh to thirteenth kings of Khotan ruled between 133 and 200 (Zhu Lishuang, "Yutian wangtong yanjiu"). 
were supported economically by the state), ${ }^{35}$ and other documents attest to its role and importance in Mahāyāna Buddhism in Asia.

The question arising from this new evidence is: what is the purpose of the Toplukdong Small Temple painting making such a strong reference to the foundation legend of the Gomatī? The possibility that the Toplukdong structure is the place where the Gomati Monastery was has to be ruled out. The exact location of the Gomatī Monastery remains unknown, and-despite previous sustained endeavours - no archaeological remains have been found. However, there is strong evidence that it could have been situated close to Mt. Gautośan (i.e. Gośrnnga), since Tibetan texts mention it in association with the Gomatī legend. According to Aurel Stein, the location of this mountain could correspond to the Hill of Kohmārī (26 kilometres southwest of modern city of Khotan), on the eastern bank of the Karakash river, close to the site of Yotkan, the ancient capital. ${ }^{36}$ Therefore, the probable location of the Gomati Monastery visited by Faxian is unmistakably out of the geographical range of the Toplukdong ruins in Domoko, which are roughly situated at a linear distance of about 120 kilometres east of Yotkan. This distance does not match any of the indications given in the ancient sources, which point, instead, to an area close to the capital itself.

In my view, more than indicating the identity of the monastery per se, the painting of the legend of the Gomati Monastery might have indicated a direct connection between the temple in Toplukdong and the Gomati Monastery situated near the capital. The need to communicate such a connection stems from the importance that the Gomati Monastery had for both the religious and royal establishments in Khotan. The Gomatī, as can be deduced from legendary and historical evidence, was not only founded by Khotanese royalty, but was also guarded by very specific deities, namely by Vaiśravana, Samjñāya, and Gṛhāvatapta. These three form part of the so-called Eight Protectors (Kh. hașțä parvālā, Chin. ba da shouhushen 八大守護神)—a group of deities that were specifically nominated by the Buddha Saakyamuni to protect the Kingdom of

35 See Antonino Forte, "Daiji (Chine)," in Hōbōgirin: dictionnaire encyclopèdique du bouddhisme d'aprés les sources chinoises et japonaises, ed. Paul Demièville et al. (Paris and Tokyo: Académie des inscriptions et belles lettres, Maison franco-japonaise, 1983), 682-704.

36 See details in Erika Forte, "Khotan chiku Domoko hakken Toplukdong 1-gō butsuji to Gomati-dera densetsu コータン地區ドモコ發見トプルクトン 1 號佛寺と睢摩帝寺 傳説. Toplukdong Temple no. 1 in Domoko (Khotan) and the legend of Gomatī monastery," in Takata Tokio kyōju taishoku kinen Tōhōgaku kenkyū ronshū 高田時雄教授退職記念東 方學研究論集 East Asian Studies. Festschrift in Honor of the Retirement of Professor TAKATA Tokio, ed. Tōhōgaku kenkyū ronshū kankōkai 東方學研究論集刊行會 (Kyoto: Rinsen Book Co., 2014), 210-227. 
Khotan and ensure its sovereignty. ${ }^{37} \mathrm{~A}$ survey in the Prophecy of the Li Country shows that four of these state-protecting gods (Vaiśravanaa, Samjñãya, the Nāga King Gṛhāvatapta, and Aparājita) often appear among the deities who appoint themselves to protect the monasteries founded by the kings in the local legends. Vaiśravana and Samjñāya were the most 'active' in guarding royal monasteries and seem to have been especially prominent among the other protectors.

Being guarded by one or more of the state protectors meant that the Buddhist monasteries benefited from 'extra-protection,' which at the same time recognizes a special bond between the Buddhist institution and the state, and expresses their mutual legitimation. The Gomatī Monastery-defended by three of the Eight Protectors - therefore appears to have been of particular importance, as a stronghold of Buddhism and likely directly involved in the protection of the kingdom of Khotan.

Conclusions: Pictorial Representations of Khotanese Legends as Expression of Patronage

The example of the Toplukdong Small Temple highlights the role pictorial representations of Buddhist legendary accounts - particularly their deliberate placement-play as conveyors of information related to the identity, origin, and function of Buddhist monasteries and temples in ancient Khotan. The painting in Toplukdong conveys the message that this institution was connected with the Gomatì Monastery. It was probably founded by members of the Khotanese royal family, and thus benefited from the same strong royal support as the Gomatī —in other words, it may have been a royal monastery itself,

The group of Eight Protectors of Khotan have their origin in Mahāyāna texts that circulated in Khotan from around the 4 th $-5^{\text {th }}$ centuries onwards, and appear, as noted by Harold Bailey, in Khotanese, Tibetan, and Chinese texts. Cf. Harold Walter Bailey, "Hvatanica IV," Bulletin of the School of Oriental and African Studies 4 (1942): 912. The protectors are: Aparājita, Saṃjñāya (Sañjaya, Saṃjñin), Gaganasvara, Suvarṇa(-)māla, Gṛhāvatapta, Aṃgūśa', Sthānavatī, and Vaiśravaṇa (Vaiśramaṇa). See Rong Xinjiang 榮新江 and Zhu Lishuang 朱丽双, “Tuwen huzheng一Yutian ba da shouhushen xin tan 图文互证一于 阗八大守护神新探 [Mutual Evidence in Pictures and Texts: New Research on the The Eight Great Protectors of Khotan]," in Dunhuang wenxian, kaogu, yishu zonghe yanjiu. Jinian Xiang Da xiansheng danchen 110 zhounian guoji xueshu yantaohui lunwenji 敦煌文 献、考古、艺术综合㸴究. 纪念向达先生诞辰 110 周年国际学术㸴讨会论文集 [Comprehensive Studies on Documents, Archaeology and Art of Dunhuang. Proceedings of the International Academic Seminar Celebrating the 11oth Anniversary of Professor Xiang Da's Birthday], ed. Fan Jinshi 樊锦诗 et al. (Beijing: Zhonghua shuju, 2011), 19o-218 (for the transcription of the names, I follow the list provided at p. 201). 
maybe even a direct 'affiliate' of the Gomatī Monastery, acting, as the Gomatī, to protect the Buddhist Kingdom of Khotan. The depiction of the legend carries sufficient elements to communicate that the building in Toplukdong was supported by the king of Khotan, and hints at its royal patronage. Probably the kings of Khotan recognised themselves in the legends, as the legends legitimated their role through Buddhism.

This model of interpretation can be extended to other depictions of local Buddhist legends from different sites in Khotan. It is possible that depictions of the Silk Princess story and the founding of the Mashe/Ma dza Monastery, which are found at sites far distant from the probable locations of the original monasteries, were meant to declare a connection with the original monastery and its royal patronage. The historical documentation of the Mashe/Ma dza Monastery does not allow us to draw any conclusion as to its role in the political and religious agenda of Khotanese establishments. We can only speculate that it could have been important that the agent at the origin of the monastery was a Chinese bride of the king of Khotan. Was the Mashe/Ma dza Monastery connected with a Chinese community in Khotan? Or was this monastery important for its link to the economically lucrative sericulture activities in the oasis?

Depictions of Khotanese legends are also found in the Dunhuang Mogao and Yulin Caves, which are both related to the Khotanese royals and the local Khotanese community. Here the connection between direct or indirect Khotanese patronage and the legends becomes more explicit. These depictions appear at the earliest in the late-8th century and continue to be present up to the 1oth century. The set of legends represented in Dunhuang are different from those found in Khotan. Recurrent themes are: The foundation legend of Khotan, which highlights the Buddhist mythological origin of the Khotanese Kingdom and kingship, particularly the scene where Śariputra and Vaiśravana dry the lake which was covering Khotan with their staffs, on the order of Śākyamuni (fig. 2.6); depictions of mount Gośîrșa, the most sacred place of Khotan, where Saakyamuni and other buddhas took up residence in the past (fig. 2.7); the complete group of the Eight Protectors; and the so-called Auspicious Statues (Chin. ruixiang 瑞像), a number of which were believed to reside in Khotan. ${ }^{38}$

$38 \quad$ The term ruixiang has also been translated into English as "auspicious images," or "famous image." For the use of the term "statues," see Michel Soymié, "Quelques représentations de statues miraculeuses dans les grottes de Touen-houang," in Contributions aux études de Touen-huang, ed. Michel Soymié (Paris: École française d'Extrême-Orient, 1984), 77-102; Christoph Anderl and Erika Forte, "Auspicious Statues 瑞像," in Brill's Encyclopedia of Buddhism, ed. Jonathan Silk (Leiden: Brill, forthcoming). 


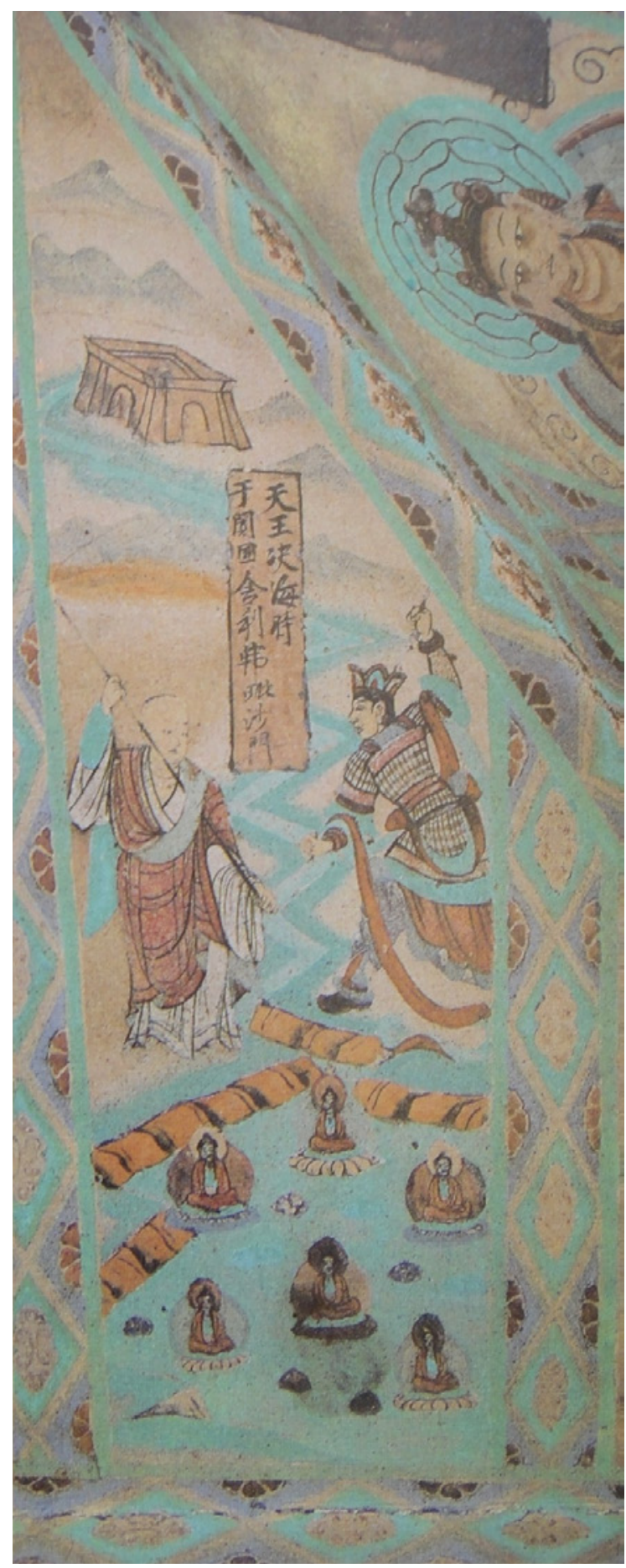

FIGURE 2.6

The founding legend of Khotan. Wall painting from the ceiling of the main chamber (western) niche of Mogao Cave 237 , end of 8th-first half of the gth c.

(C) DUNHUANG ACADEMY 


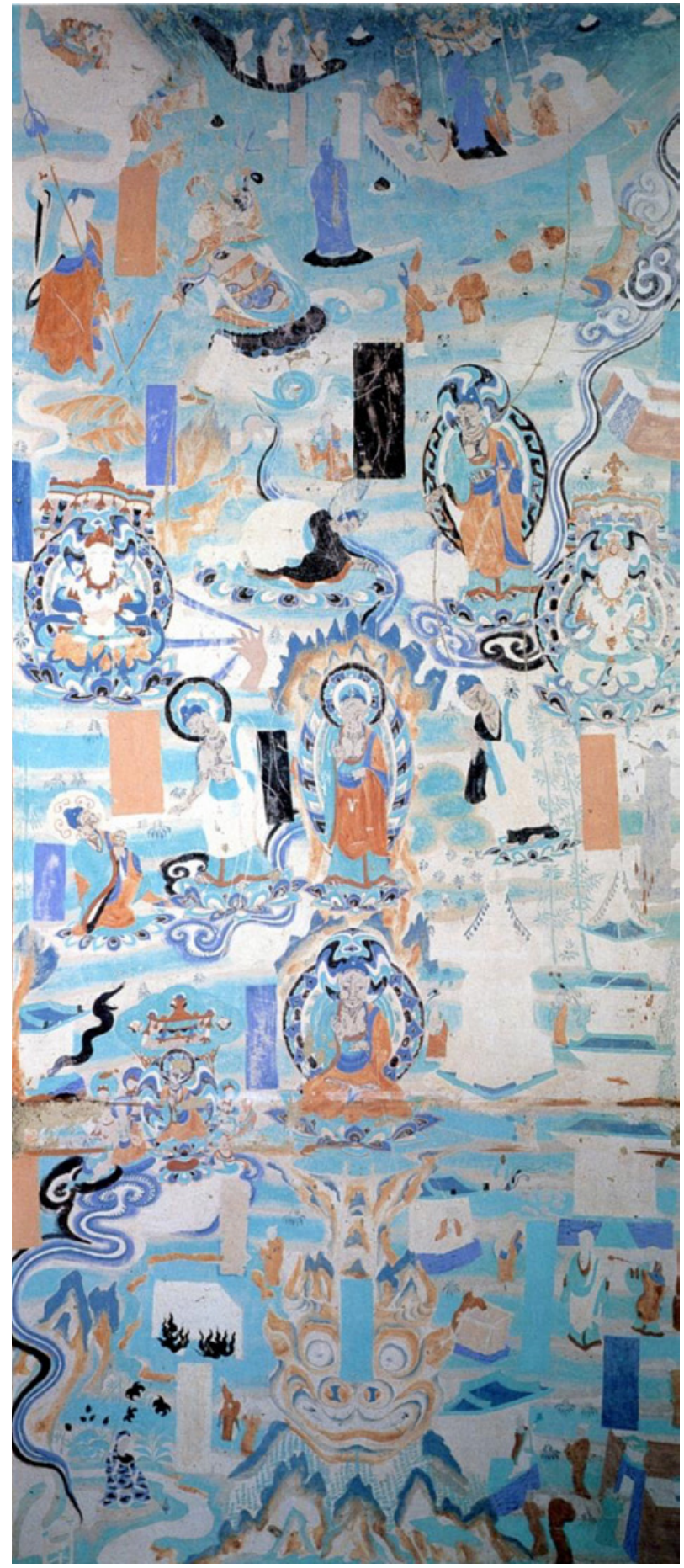

FIGURE 2.7

Depiction of Mt. Gośīișa/ Gośrnnga. Wall painting from the ceiling of the entrance corridor of Mogao Cave 9, 9th c. SUN XIUSHENG, ED., DUNHUANG SHIKU QUANJI 12: FOJIAO DONGCHUAN GUSHIHUA JUAN (2000), 90, FIG. 72 


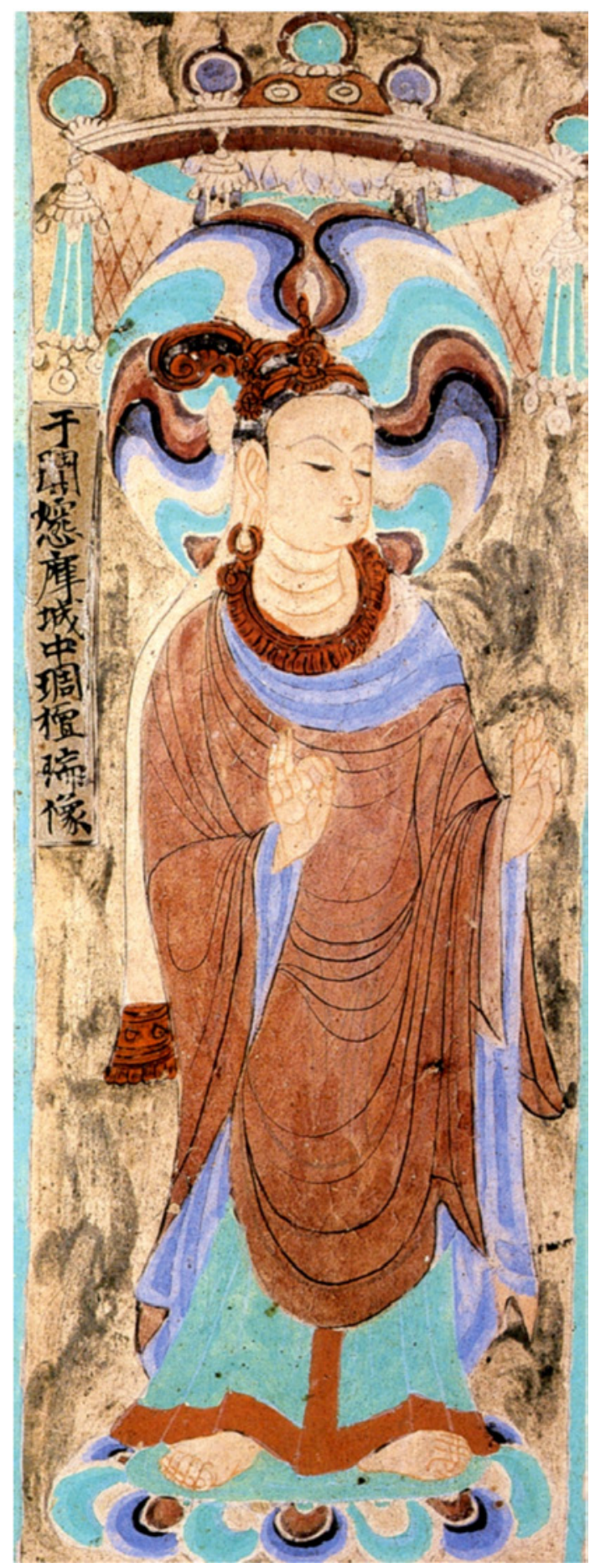

FIGURE 2.8

The auspicious image of Pimo. Wall painting from the main chamber western niche ceiling of Mogao Cave 231, 9th c. ZHANG XIAOGANG, DUNHUANG FOJIAO GANTONGHUA YANJIU (2015), 128, FIG. 2-1-3. 
The legends related to the 'Khotanese' Auspicious Statues are recorded in Chinese literature. ${ }^{39} \mathrm{~A}$ well-known story is of the miraculous statue that flew through the air from India to Khotan, landing in a place known in the Chinese sources as Pimo (謧摩) or Hanmo (捍麼) (fig. 2.8). According to Xuanzang, this was the very first image of the Buddha, which the king Udayana of Kauśāmbī had carved from sandalwood while the Buddha was still alive. The king of Khotan financed the construction of a monastic complex to host the statue in Pimo, and the place became an important centre for pilgrimage.

Interestingly, the legends that are depicted in Khotan are not found in Dunhuang, and vice versa; none of the subjects of Khotanese imagery from Dunhuang can be clearly identified among the surviving paintings in Khotan. So far, not a single depiction of the foundation legend has been found in Khotan, nor of the complete group of the Eight Protectors, although the identification of some depictions of standing buddhas on wooden panels as Auspicious Statues remains tentative. ${ }^{40}$ The reasons for this state of evidence are unclear. Could they be a lacuna in the documentation? The result of a specific choice? Or different attitudes in time and space? These are topics that needs further investigation.

39 Zhang Guangda 张广达 and Rong Xinjiang 榮新江, "Dunhuang Ruixiangji, ruixiangtu ji qi fanyingde Yutian 敦煌瑞象记, 瑞象图及其反映的于阗, The Records of Famous Images, the Painting of Famous Images from Dunhuang and Khotan as Reflected in Them," in Yutian shi congkao (Zengding Ben) 于䀠史叢考(増訂本). Collected Inquiries on the History of Khotan. New Edition, ed. Zhang Guangda 张广达 and Rong Xinjiang 荣 新江 (Beijing: Zhongguo Renmin Daxue chubanshe, 2008), 166-223. See also Christoph Anderl, "Linking Khotan and Dūnhuáng: Buddhist Narratives in Text and Image," Entangled Religions 5 (2018): 250-311, accessed June 11, 2019. doi: 10.13154/er.v5.2018.250-311. Williams, "Khotanese Paintings," 125-128. 